\title{
FLORISTIC-STRUCTURAL CHARACTERIZATION AND SUCCESSIONAL GROUP OF TREE SPECIES IN THE CERRADO BIOME OF TOCANTINS STATE, BRAZIL $^{1}$
}

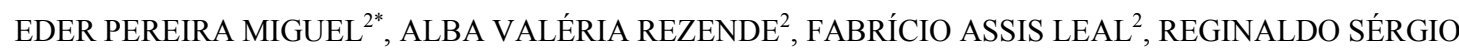 \\ PEREIRA $^{2}$, RAFAEL RODOLFO DE MELO 3
}

\begin{abstract}
The objective of this study was to characterize the floristic composition, vegetation structure and ecological group of tree species in a cerradão forest (Cerrado biome) of Palmas, Tocantins State, Brazil. A forest inventory was performed in an area of 10.15 hectares, using systematic sampling with plots of $400 \mathrm{~m}^{2}$, in which all standing trees, alive and dead, that had diameter at breast height $(\mathrm{DBH}) \geq 5 \mathrm{~cm}$ were sampled and identified. A linear plateau regression model (LPR) was used for sample sufficiency analysis. The Shannon index $\left(\mathrm{H}^{\prime}\right)$ was used for assess the floristic diversity, and the Importance Value Index (IVI) for assess the horizontal structure. The forest was classified in three strata according to vertical structure analysis. The LPR showed that the sampling size was adequate. The predominate species in the area were Myrcia splendens, Emmotum nitens and Qualea parviflora, and species from the families Fabaceae and Chrysobalanaceae. The pioneer (613 individuals $\mathrm{ha}^{-1}$ ) and climax (530 individuals $\mathrm{ha}^{-1}$ ) species were the predominating groups. Regarding the richness index, the number of climax (57 species) and pioneer (25 species) species stood out. The alpha floristic diversity was 3.35 nats individuals ${ }^{-1}$ and the Pielou equability value $\mathrm{J}=0.76$. The diametric distribution showed a negative and balanced exponential pattern. Regarding the vertical stratification, the smallest amount of individuals was in the upper stratum (13\%) and the highest in the mid stratum $(63 \%)$ and in the lower stratum (24\%). The use of floristic composition tools with horizontal and vertical structure analysis was effective for understand the tree community, which may be considered structured and diverse, thus able to restructure possible disturbances when preserved.
\end{abstract}

Keywords: Floristic diversity. Phytosociology. Balanced forest. Ecological groups.

\section{CARACTERIZAÇÃO FLORÍSTICO-ESTRUTURAL E GRUPO SUCESSIONAL DE ESPÉCIES ARBÓREAS NO BIOMA CERRADO DO ESTADO DE TOCANTINS, BRASIL}

\begin{abstract}
RESUMO - Objetivo deste estudo foi caracterizar a composição florística, a estrutura da vegetação e os grupos ecológicos das espécies arbóreas em área de cerradão em Palmas, Tocantins. Foi realizado um inventário florestal em área de 10,15 hectares, utilizando amostragem sistemática com parcelas de $400 \mathrm{~m}^{2}$, onde foram amostradas e identificadas todas as árvores vivas e mortas em pé, com DAP $\geq 5 \mathrm{~cm}$. Na análise da suficiência amostral utilizou-se a regressão linear com resposta em platô (REGRELRP). A diversidade florística foi avaliada pelo o índice Shannon (H') e a estrutura horizontal pelo o Índice de Valor de Importância (IVI). Na análise da estrutura vertical, a floresta foi classificada em três estratos. A REGRELRP revelou que a intensidade amostral foi adequada. Predominam na área as famílias Fabaceae e Chrysobalanaceae, e as espécies Myrcia splendens, Emmotum nitens e Qualea parviflora. O grupo composto por espécies pioneiras predominam (613 indivíduos $\mathrm{ha}^{-1}$ ), e as climácicas (530 indivíduos ha $\mathrm{ha}^{-1}$ ). No quesito riqueza, as espécies clímax sobressaíram (57 espécies), pioneiras (25 espécies). A diversidade alfa florística foi de 3,35 nats indivívideos ${ }^{-1} \mathrm{e}$ $\mathrm{o}$ valor de equabilidade de Pielou $\mathrm{J}=0,76$. A distribuição diamétrica apresentou comportamento exponencial negativo e balanceada. Em relação aos estratos verticais, a menor quantidade de indivíduos é encontrada no estrato superior $(13 \%)$, a maior no estrato médio $(63 \%)$ e o estrato inferior (24\%). A área estudada foi caracterizada como estruturada e diversa conforme composição florística e fitossociológica encontrada, apresentou heterogeneidade de espécies, predominantemente clímax. O cerradão apresentou bom estado de conservação, demostrando sua capacidade de resiliência a pequenos distúrbios.
\end{abstract}

Palavras Chaves: Diversidade florística. Fitossociologia. Floresta balanceada. Grupos ecológicos.

\footnotetext{
*Corresponding author

${ }^{1}$ Received for publication in $02 / 27 / 2015$; accepted in 03/08/2016.

Paper extracted from the doctoral thesis of the first author, funded by CNPq.

${ }^{2}$ Department of Forest Engineering, Universidade de Brasília, Brasília, DF, Brazil; miguelederpereira@gmail.com, albavr@unb.br, fabricioassisleall@gmail.com, reginaldosp@unb.br.

${ }^{3}$ Institute of Agricultural and Environmental Sciences, Universidade Federal do Mato Grosso, Sinop, MT, Brazil; rrmelo2@yahoo.com.br.
} 


\section{INTRODUCTION}

Tropical forest characteristics has risen great interest in floristic-structural studies due to the wide variety of ecological patterns and processes relevant to its diversity. In recent years, researchers have brought to attention the importance of knowledge on the Cerrado biome (Brazilian Savanna) flora. This biome has one of the richest and diverse flora in the world, distributed in diverse physiognomic types, including forests, savannas, and grasslands. It is the second largest biome in Brazil, with approximately two hundred million hectares (RATTER, RIBEIRO, BRIDGEWATER, 1997).

Among the cataloged Cerrado plant species, $35 \%$ were classified as endemic, which correspond to $1.5 \%$ of the endemic flora of the world (MYERS et al., 2000). The latest survey on Cerrado flora found more than 12,000 species (MENDONÇA et al., 2008), however, this number is certainly much higher, since there are many Cerrado areas that have not yet been scientifically investigated. Some studies consider that the Cerrado great richness and floristic diversity is mainly due to its landscapes diversity and physiognomic types.

The Cerrado vegetation is characterized by a mosaic of physiognomic types, which includes forests (cerradão, dry forest, gallery forest and riparian forest), savannas (cerrado sensu stricto, cerrado park, palm trees and vereda) and grasslands (grassland, dry grassland and rupestrian fields). Among the Cerrado forest forms is the cerradão, which is usually associated with interfluvial areas, well-drained lands, and deep soils (SOLÓRZANO et al., 2012).

Cerradão is commonly found in Latosols, with low and mid fertility, but it is also found in dystrophic Cambisols (RIBEIRO; WALTER, 2008). The cerradão may be classified in two types: (1) Mesotrophic (cerradão, found in soils with medium levels of nutrients and $\mathrm{pH}$ between 5.5 and 7.0; whose predominant species are Anadenanthera colubrina, Dilodendron bipinnatum, Dipteryx alata, Myracrodruon urundeuva, Pseudobombax tomentosum and Terminalia argentea) and (2) Dystrophic (cerradão, found in soils with $\mathrm{pH}$ ranging from 4.0 and 4.8 , with calcium content less than 0.5 meq/100g (HARIDASAN; ARAÚJO, 2005) and predominance of Emmotum nitens, Tachigale vulgaris, Tapirira guianensis and Virola sebifera).

Cerradão areas have been deforested for agricultural purposes for many decades (FELFILI; CARVALHO; HAIDAR, 2005). The few remaining areas are found in small fragments in all Brazilian states where the Cerrado biome is predominant. Therefore, it is important to conduct studies in these remaining areas, seeking to improve the floristic, structural and production aspects of the cerradão vegetation, since such information is essential to assess the potential of a forest and proper definition of its use (FRANCEZ; CARVALHO; JARDIM, 2007).

Moreover, information about the flora and vegetation structure of a community are also essential to establish strategies for conservation and rational use of a ecosystem (SILVA et al., 2006), and correlations with certain intrinsic characteristics of the species, such as phenology, light requirement, water and nutrients, as well as the growth time and patterns, can provide information for vegetation classification in successional groups (SANTOS et al., 2004).

The area studied was characterized as structured and diverse regarding phytosociological and floristic composition, showing heterogeneity of species, predominantly climax. The cerradão forest showed good overall conditions and resilience to potential disturbances.

\section{MATERIAL AND METHODS}

This study was conducted in a cerradão forest fragment of about 10.15 ha, located between the parallels $10^{\circ} 10^{\prime} 55^{\prime \prime S}$ and $10^{\circ} 11^{\prime} 20^{\prime \prime S}$ and the meridians $48^{\circ} 10^{\prime} 50^{\prime \prime} \mathrm{W}$ and $48^{\circ} 10^{\prime} 30^{\prime \prime} \mathrm{W}$, in the Lajeado State Park, Palmas, Tocantins State, Brazil. This park was created on 2001 over an area of 9,931 ha of Cerrado biome. Local climate is C2wA'a' according to the Köppen (1936) classification. The region presents flat and wavy terrains with predominance of Dystrophic Red Latosol (EMBRAPA, 2011).

The cerradão woody vegetation was inventoried using the systematic sampling procedure (PÉLLICO NETTO; BRENA, 1997), with 54 plots of $400 \mathrm{~m}^{2}(20 \times 20 \mathrm{~m})$ launched and marked permanently, totaling 2.16 ha. All standing trees, alive and dead, that had diameter at breast height (DBH) (diameter at $1.30 \mathrm{~m}$ above the ground) equal or higher than $5 \mathrm{~cm}$, were sampled and identified in each plot. The diameters were measured using a caliper rule and the height using a $15 \mathrm{~m}$ telescopic scale. Trees over $15 \mathrm{~m}$ high had their heights visually estimated.

Botanical collections were performed. The material collected for identification (vegetative and fertile materials) was pressed and dried in a greenhouse (MORI et al., 1989). The species were classified according to the system proposed by the Angiosperm Phylogeny Group (APG III, 2009), mainly in loco by researches or consulting analytical keys in the herbaria of Brasilia University.

Species-area curve was used to assess whether the sampled area was sufficient to represent the floristic richness of the cerradão (MÜELLERDOMBOIS; ELLEMBERG, 2002), using a linear plateau regression model (LPR). The regression model fit was performed by the Solver method of Microsoft $^{\circledR}$ Excel. The linear plateau regression 
model used was $Y_{i}=\beta_{0}+\beta_{1} \mathrm{X}+\varepsilon_{\text {, }}$ where $Y$ is the species cumulative number in $i$ sampled plots, $\mathrm{X}$ is number of sampled plots, $\beta_{0}$ and $\beta_{1}$ are regression equation parameters to be estimated, and $\varepsilon$ is the error associated with the model.

The cerradão arboreal flora was characterized considering the composition and the species richness and diversity. The alpha diversity was obtained from the Shannon diversity index $\left(\mathrm{H}^{\prime}\right)$ and the equability by the Pielou index $(\mathrm{J})$.

The vegetation structure was also assessed, considering both horizontal and vertical structures. Regarding the horizontal structure, the phytosociological variables and the diameter distribution were assessed.

The phytosociological variables: basal area, density, frequency and importance value index (KENT, COKER, 1999; MÜLLER-DOMBOIS; ELLEMBERG, 2002) were assessed using the Mata Nativa 3 software (CIENTEC, 2010). The diametric distribution was assessed considering the class interval of $5 \mathrm{~cm}$, aiming to compare with other studies in areas of cerradão (CAMILOTTI; PAGOTTO; ARAÚJO, 2011; TOPPA; PIRES; DURIGAN, 2004; COSTA; ARAÚJO, 2001).

The Lioucourt quotient "q" (MEYER et al., 1961) was used to assess whether the cerradão vegetation was balanced. The following relation must find the " $\mathrm{q}$ " value:

$$
q=\frac{n_{1}}{n_{2}}=\frac{n_{2}}{n_{3}}=\frac{n_{9}}{n_{4}}=\frac{n_{m_{2}-1}}{n_{12}}
$$

where $n_{1}$ is the number of individuals at the first diameter class, $\mathrm{n}_{2}$ is the number of individuals at the second diameter class, and $\mathrm{n}_{\mathrm{n}}$ is the number of individuals at the nth diameter class.

Vegetation stratification was performed, resulting in three classes of total height (HT), in order to assess the cerradão vertical structure, as suggested by Souza et al. (2003). The lower stratum (EI) had HT $<(\mathrm{Hm}-1 \sigma)$, mid stratum (EM) had $(\mathrm{Hm}-1 \sigma)<\mathrm{HT}<(\mathrm{Hm}+1 \sigma)$ and upper stratum (ES) had $\mathrm{HT}>(\mathrm{Hm}+1 \sigma)$, where $\mathrm{Hm}$ is the total mean height and $\sigma$ is the standard deviation of total height (HT) of the sampled trees.

The cerradão species were classified according to its ecological importance, considering the representation of each one in the vertical structure of the community. Therefore, Absolute Sociological Position (PSAi) and Relative Sociological Position (PSRi) parameters were used according to Finol (1971):

$$
\begin{aligned}
& P S A_{i}=\sum_{j=1}^{j}\left(\frac{N j}{N}\right) \cdot N i j \\
& P S R_{i}=\frac{P S A_{i}}{\sum_{i=}^{S} P S A_{i}} \cdot 100
\end{aligned}
$$

where:

$\mathrm{N}_{\mathrm{j}}=$ number of individuals of the $\mathrm{i}_{\text {th }}$ stratum;

$\mathrm{N}=$ total number of individuals of all species in all strata;

$\mathrm{N}_{\mathrm{ij}}=$ number of individuals of the $\mathrm{i}_{\mathrm{th}}$ specie in the $\mathrm{j}_{\mathrm{th}}$ height strata;

$\mathrm{S}=$ total number of sampled species.

The species were classified according to successional group suggested by Swaine and Whitmore (1988), using also information available in the literature (ABREU; PINTO; MEWS, 2014; CARVALHO, 2003; 2006; 2008; RESSEL et al., 2004; LORENZI, 2002). Pioneer species (whose seeds germinate only in opening areas and has completely open canopy, receiving direct radiation in at least part of the day, and those with seedlings with quick development) and climax (species whose seeds may germinate under shade and seedlings are found under the canopy, but may also be found in open environment with slow to moderate growth).

The ecological importance of families was estimated by the Family Importance Value Index (IVIF), through the sum of the diversity relative values (number of family species by the total number of species), density and dominance (MORI; BOOM, 1983).

\section{RESULTS AND DISCUSSION}

The plateau response curve of the cerradão arboreal flora (Figure 1) was generated from the linear equation $\mathrm{Y}=35.8951+1.090$. $\mathrm{X}$ $\left(\mathrm{R}^{2}=0.91\right.$ and $\left.\mathrm{S}_{\mathrm{yx}}=7.81 \%\right)$, and fitted to represent the increase of floristic richness in relation to the increase of the studied area. This result showed that the sampled area of 2.16 ha was enough to represent the floristic richness of cerradão arboreal community, since, from 1.6 ha the curve stabilizes, forming a plateau. Therefore, the 54 plots of 0.04 ha (2.16 ha) extrapolates in $26 \%$ the minimum area considered enough to represent the floristic richness of that community. 


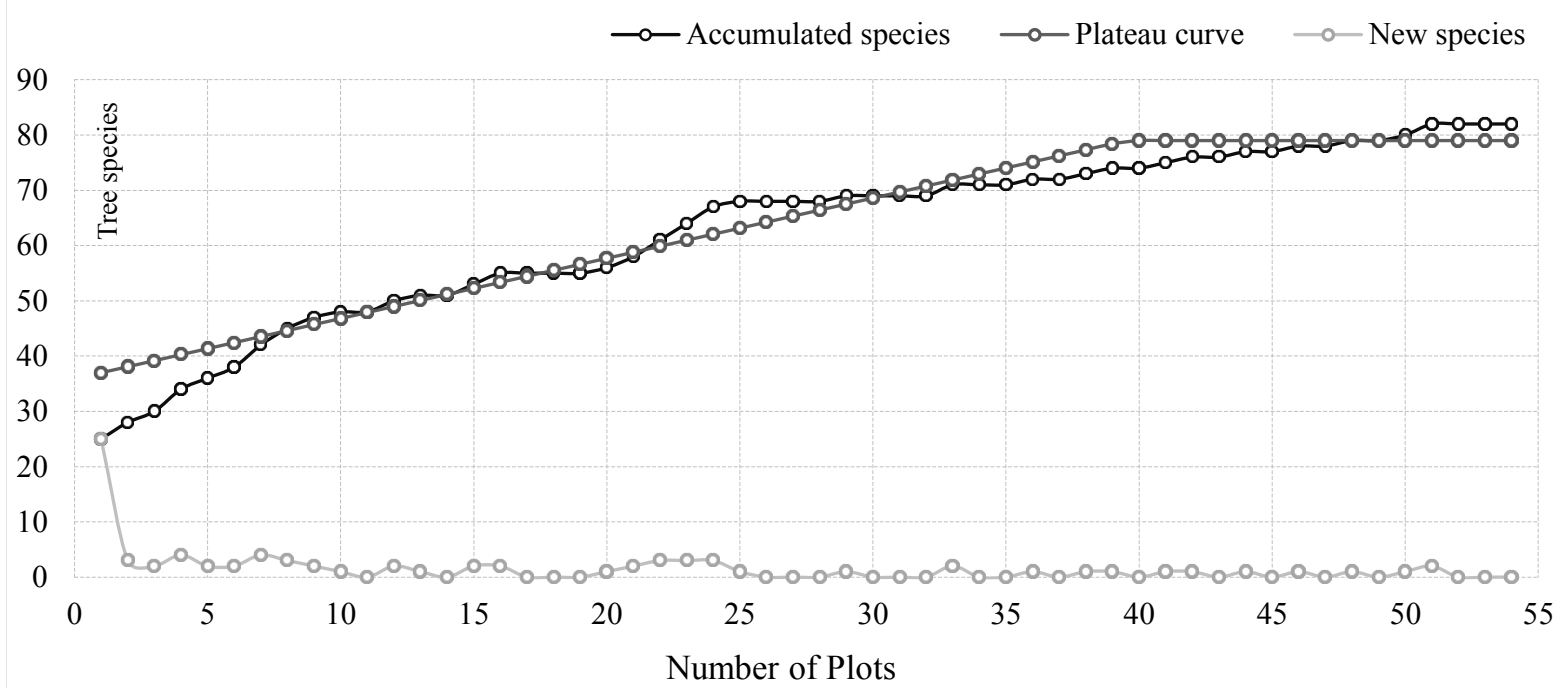

Figure 1. Curve of accumulated species and area, plateau curve, and emergence of new species, in an area of 2.16 hectares inventoried in a cerradão forest in Palmas, Tocantins State, Brazil.

The results show that with a minimum sampled area (asymptote) of 1.6 ha is possible to find $96 \%$ (79 of 82 ) of the total number of species found in the 2.16 ha. Such value is higher than the value found by Pires-O'Brien and O'Brien (1995), which suggest that the minimum area sampled in tropical forests shall include, at least, $90 \%$ of the community species sampled. However, tropical forests present high floristic richness, thus the species-area curve, in general, is not able to stay fully stabilized, even with large sample intensities, unless a census is carried out (SCHILLING; BATISTA, 2008; OLIVEIRA et al., 2008).

Approximately 1,228 tree $^{-1} \mathrm{~h}^{-1}$ were registered in the cerradão area with diameter $(\mathrm{DBH})$ ranging from $5 \mathrm{~cm}$ to $65 \mathrm{~cm}$, mean of $11.55 \mathrm{~cm}(\mathrm{CV} \pm 60.15$ $\%$, and total height ranging from $3 \mathrm{~cm}$ to $21 \mathrm{~m}$, mean of $9 \mathrm{~m}(\mathrm{CV} \pm 28.16 \%)$. This density is within the normally range found in other sampled areas of cerradão within the Cerrado biome, which ranges from 1,172 to 1,251 tree ha ${ }^{-1}$ (SOUZA et al., 2010; SOUZA et al., 2008).

The basal area of the arboreal community of the cerradão was $17.34 \mathrm{~m}^{2} \mathrm{ha}^{-1}$. This basal area is also within the limit found in other cerradão areas (from 17.05 to $24.9 \mathrm{~m}^{2} \mathrm{ha}^{-1}$ ). Around $7 \%$ (85 trees) of the amount of standing trees was dead, result that was similar to that found in other cerradão areas classified as dystrophic (MARIMON JUNIOR; HARIDASAN, 2005). Therefore, this tree population also has an important role in cerradão community.

Regarding the floristic, 34 botanical families were found (Table 1), 16 in only one sampled plot, with density equal to one. The most representative families in the area were the Fabaceae (15), Chrysobalanaceae (7), Apocynaceae (5), Melastomataceae (5), Malpighiaceae (4), Vochysiaceae (4), Anacardiaceae (3) and Connaraceae (3). These families comprise $56 \%$ of all species sampled in the cerradão. According to Felfili et al. (2004), the Fabaceae and Vochysiaceae families are the most studied families in cerradão of the Federal District. The predominance of leguminous species may be attributed to the biological nitrogen fixation capacity in many leguminous species, which facilitates the regeneration in low fertility and degraded soils (SOUZA et al., 2010). Moreover, many species of this family regrow from roots (RODRIGUES et al., 2004). The species from the Myrtaceae family found in this study is mainly Myrcia splendens, due to its high density.

The species Myrcia splendens, Emmotum nitens, Miconia albicans, Qualea parviflora, Xylopia aromatica and Tapirira guianensis were the most abundant species in the area, and together, they represent more than $60 \%$ of all surveyed individuals. This result differed from that found by Souza et al. (2010) in cerradão areas of Minas Gerais State, who found Myracrodruon urundeuva, Callisthene major and Rollinia sylvatica as predominant species. However, Solórzano et al. (2012) and Silva et al. (2008) found the species Caryocar coriaceum, Emmotum nitens and Tapirira guianensis, which were all also found in this study. The domain of species groups in the cerradão areas confirms the statements of Ratter (1971); Ratter et al. (1973); Ratter (1987), about the existence of two distinct types of cerradão.

Among the species found in the study area, 10 $(12.20 \%)$ were responsible for $63.21 \%$ of the total IVI, they were Myrcia splendens (12.43\%), Emmotum nitens (10.12\%), Qualea parviflora (7.42\%), Xylopia aromatica (6.34\%), Tapirira guianensis (6.24\%), Miconia albicans (5.69\%), Parkia platycephala (4.28\%), Caryocar coriaceum (3.85\%) Tachigale vulgaris (3.72\%) and Mezilaurus itauba (3.12\%). Only Mezilaurus itauba from those is not common to cerrado sensu stricto environments and seasonal forests. These two phyto- 
physiognomies shows species commonly found in cerradão (MENDONÇA et al., 2008; FELFILI et al., 2004; PROENÇA et al., 2001). Mezilaurus itauba presents an Amazon phyto-geographical domain, although there are records of the species in cerradão areas in the State of Mato Grosso/Amazon (ARAÚJO et al., 2009).

The Myrcia splendens species presented the highest IVI in the area and stood out because its high density. However, in other cerradão areas, located in the States of São Paulo, Mato Grosso, Mato Grosso do Sul, Minas Gerais, Goiás and the Federal District, this species have not stood out (GUILHERME; NAKAJIMA, 2007; MARIMON JUNIOR; HARIDASAN, 2005; COSTA; ARAÚJO, 2001). In a floristic survey performed by Solórzano et al. (2012) in a cerradão area of Tocantins, this species was among the most important, indicating that it may be common in the cerradão of this State.

The cerradão alpha diversity was 3.35 nats individuals $\mathrm{s}^{-1}$. This value was within the range of floristic diversity found in other cerradão areas by Solórzano et al. (2012) (2.92 to 3.54 nats individuals $\left.{ }^{-1}\right)$. The Pielou equality was 0.76 , which was within the values previously found in cerradão areas $(0.73$ and 0.91) (GUILHERME; NAKAJIMA，2007; SALIS et al., 2006). The equality value found in this cerradão indicates that a reasonable diversity, with values higher than $76 \%$ of the maximum possible (Hmax), resulting in the possible dominance of certain species in the area (MAGURRAN, 2004), which was confirmed in this study.

Three strata were defined for vertical structure of the cerradão community as lower stratum $(\mathrm{HT}<6.41 \mathrm{~m})$; mid stratum $(6.41 \leq \mathrm{HT}<11.54)$ and upper stratum $(\mathrm{HT} \geq 11.54)$. The lowest amount of trees was found in the upper stratum (ES), with 325 individuals (13\%), which suggests that few individuals of the community are able to reach the upper canopy. The middle stratum (EM) had the highest amount found, with 1,565 individuals (63\%), and 591 individuals $(24 \%)$ was found for the lower stratum (EI). Therefore, considering the species representativeness in vertical structure of the cerradão community, it was possible to distinguish four species that stood out as the most found Relative Sociological Position (PSRi), the Myrcia splendens (16.05\%), Emmotum nitens (11.44 \%), Xylopia aromatica $(8.62 \%)$ and Qualea parviflora $(8.30 \%)$, as shown in Table 1.

Table 1. Vertical and horizontal structure, successional groups and phytosociological variables of arboreal species found in a cerradão area located in the Lajeado State Park, Palmas, Tocantins State, Brazil. EI = lower stratum $(\mathrm{HT}<6.41 \mathrm{~m}), \mathrm{EM}=$ mid stratum $(\mathrm{HT} \leq 6.41 \mathrm{~m}<11.54)$, ES = upper stratum $(\mathrm{HT}>11.54 \mathrm{~m})$; PSA = absolute sociological position; PSR = relative sociological position; $\mathrm{EG}=$ ecological group $(\mathrm{PI}=$ pioneer, $\mathrm{CL}=$ climax $) ; \mathrm{DA}=$ absolute density; $\mathrm{DR}=$ relative density; FA = absolute frequency; FR = relative frequency; DoA = absolute dominance; DoR = relative density; IVI $(\%)=$ importance value index; IVIF = family importance value index.

\begin{tabular}{|c|c|c|c|c|c|c|c|c|c|c|c|c|c|}
\hline \multirow[b]{2}{*}{ Family/Species } & \multicolumn{5}{|c|}{ Vertical Structure } & \multicolumn{8}{|c|}{ Horizontal Structure } \\
\hline & EI & EM & ES & PSA & PSR & EG & DA & DR & FA & FR & DoA & DoR & $\begin{array}{l}\text { IVI } \\
(\%)\end{array}$ \\
\hline $\begin{array}{l}\text { Tapirira guianensis Aubl. } \\
\text { Tapirira obtusa (Benth.) J. D. }\end{array}$ & 2 & 121 & 48 & 60.55 & 7.06 & PI & 169 & 6.83 & 109 & 3.48 & 2.96 & 8.43 & 6.24 \\
\hline Mitch. & 11 & 20 & & 11.66 & 1.36 & PI & 30 & 1.22 & 65 & 2.06 & 0.42 & 1.20 & 1.49 \\
\hline $\begin{array}{c}\text { Thyrsodium spruceanum Benth. } \\
\text { Anacardeacea }\end{array}$ & 13 & $\begin{array}{c}1 \\
142\end{array}$ & 48 & $\begin{array}{c}0.36 \\
72.56\end{array}$ & $\begin{array}{l}0.04 \\
8.47\end{array}$ & PI & $\begin{array}{c}1 \\
201\end{array}$ & 0.04 & 4 & 0.13 & 0.00 & $\begin{array}{l}0.01 \\
\text { IVIF }\end{array}$ & $\begin{array}{l}0.06 \\
7.79\end{array}$ \\
\hline Bocageopsis multiflora (Mart.) & & & & & & & & & & & & & \\
\hline $\begin{array}{l}\text { R.E.Fr. } \\
\text { Xylopia aromatica (Lam.) Mart. } \\
\text { Annonaceae }\end{array}$ & $\begin{array}{l}10 \\
10\end{array}$ & $\begin{array}{c}3 \\
183 \\
186\end{array}$ & $\begin{array}{c}7 \\
14 \\
21\end{array}$ & $\begin{array}{c}3.60 \\
73.85 \\
77.45\end{array}$ & $\begin{array}{l}0.42 \\
8.62 \\
9.04\end{array}$ & $\begin{array}{l}\text { CL } \\
\text { PI }\end{array}$ & $\begin{array}{c}10 \\
207 \\
217\end{array}$ & $\begin{array}{l}0.41 \\
8.33\end{array}$ & $\begin{array}{c}20 \\
177\end{array}$ & $\begin{array}{l}0.64 \\
5.67\end{array}$ & $\begin{array}{l}0.08 \\
1.76\end{array}$ & $\begin{array}{l}0.23 \\
5.02 \\
\text { IVIF }\end{array}$ & $\begin{array}{l}0.43 \\
6.34 \\
6.77\end{array}$ \\
\hline Aspidosperma macrocarpon & & & & & & & & & & & & & \\
\hline Mart. & 2 & 2 & 2 & 2.00 & 0.23 & CL & 6 & 0.24 & 8 & 0.26 & 0.13 & 0.37 & 0.29 \\
\hline Aspidosperma subincanum Mart. & 5 & 25 & & 10.57 & 1.23 & $\mathrm{CL}$ & 30 & 1.22 & 81 & 2.58 & 0.37 & 1.06 & 1.62 \\
\hline $\begin{array}{l}\text { Hancornia speciosa Gomes } \\
\text { Himatanthus obovatus (Müll. }\end{array}$ & 5 & 1 & & 1.09 & 0.13 & & 6 & 0.24 & 16 & 0.52 & 0.03 & 0.09 & 0.28 \\
\hline $\begin{array}{l}\text { Arg.) Woodson } \\
\text { Himatanthus articulatus (Vahl) }\end{array}$ & 1 & & & 0.74 & 0.09 & $\mathrm{CL}$ & 1 & 0.04 & 4 & 0.13 & 0.00 & 0.01 & 0.06 \\
\hline $\begin{array}{l}\text { Woodson } \\
\text { Apocynaceae }\end{array}$ & $\begin{array}{c}2 \\
15\end{array}$ & $\begin{array}{c}4 \\
32\end{array}$ & $\begin{array}{l}1 \\
3\end{array}$ & $\begin{array}{c}1.12 \\
15.51\end{array}$ & $\begin{array}{l}0.13 \\
1.81\end{array}$ & CL & $\begin{array}{c}7 \\
50\end{array}$ & 0.28 & 24 & 0.77 & 0.11 & $\begin{array}{c}0.32 \\
\text { IVIF }\end{array}$ & $\begin{array}{l}0.46 \\
2.71\end{array}$ \\
\hline $\begin{array}{l}\text { Schefflera vinosa Frodin \& } \\
\text { Fiaschi }\end{array}$ & & & 1 & 0.36 & 0.04 & CL & 1 & 0.04 & 4 & 0.13 & 0.01 & 0.03 & 0.07 \\
\hline $\begin{array}{c}\text { Araliaceae } \\
\text { Piptocarpha macropoda (DC.) }\end{array}$ & 0 & 0 & 1 & 0.36 & 0.04 & & 1 & & & & & IVIF & 0.07 \\
\hline Baker Asteraceae & $\begin{array}{l}7 \\
7\end{array}$ & $\begin{array}{l}1 \\
1\end{array}$ & 0 & $\begin{array}{l}2.66 \\
2.66\end{array}$ & $\begin{array}{l}0.31 \\
0.31\end{array}$ & PI & $\begin{array}{l}8 \\
8\end{array}$ & 0.33 & 32 & 1.03 & 0.05 & $\begin{array}{l}0.15 \\
\text { IVIF }\end{array}$ & $\begin{array}{l}0.50 \\
0.50\end{array}$ \\
\hline $\begin{array}{l}\text { Protium heptaphyllum (Aubl.) } \\
\text { Marchand } \\
\text { Tetragastris altissima (Aubl.) }\end{array}$ & 10 & 3 & & 4.57 & 0.53 & PI & 13 & 0.53 & 36 & 1.16 & 0.08 & 0.24 & 0.64 \\
\hline Swart & & 1 & & 0.37 & 0.04 & PI & 1 & 0.04 & 4 & 0.13 & 0.01 & 0.02 & 0.06 \\
\hline
\end{tabular}


Table 1. Continuation.

\begin{tabular}{|c|c|c|c|c|c|c|c|c|c|c|c|c|c|}
\hline \multirow[b]{2}{*}{ Family/Species } & \multicolumn{5}{|c|}{ Vertical Structure } & \multirow[b]{2}{*}{ EG } & \multicolumn{7}{|c|}{ Horizontal Structure } \\
\hline & EI & EM & ES & PSA & PSR & & DA & DR & FA & FR & DoA & DoR & $\begin{array}{l}\text { IVI } \\
(\%)\end{array}$ \\
\hline Burseraceae & 10 & 4 & 0 & 4.95 & 0.58 & & 14 & & & & & IVIF & 0.70 \\
\hline Caryocar coriaceum Wittm. & 3 & 39 & 8 & 18.02 & 2.10 & $\mathrm{CL}$ & 50 & 2.03 & 109 & 3.48 & 2.12 & 6.03 & 3.85 \\
\hline Caryocaraceae & 3 & 39 & 8 & 18.02 & 2.10 & & 50 & & & & & IVIF & 3.85 \\
\hline \multicolumn{14}{|l|}{ Couepia grandiflora (Mart. } \\
\hline Zucc.) Benth. & 1 & & & 0.27 & 0.03 & $\mathrm{CL}$ & 1 & 0.04 & 4 & 0.13 & 0.00 & 0.01 & 0.06 \\
\hline Hirtella ciliata Mart. Zucc. & & 2 & & 0.74 & 0.09 & PI & 2 & 0.08 & 8 & 0.26 & 0.02 & 0.04 & 0.13 \\
\hline Hirtella glandulosa Spreng. & & 1 & & 0.74 & 0.09 & $\mathrm{CL}$ & 1 & 0.04 & 4 & 0.13 & 0.03 & 0.08 & 0.08 \\
\hline Licania apetala (E.Mey.) Fritsch & 1 & 8 & 4 & 4.44 & 0.52 & $\mathrm{CL}$ & 13 & 0.53 & 36 & 1.16 & 0.16 & 0.45 & 0.71 \\
\hline Licania egleri Prance & 1 & 8 & 1 & 3.50 & 0.41 & $\mathrm{CL}$ & 10 & 0.41 & 16 & 0.52 & 0.09 & 0.27 & 0.40 \\
\hline \multicolumn{14}{|l|}{ Licania gardineri (Hook.f.) } \\
\hline Fritsch & 1 & 2 & & 0.98 & 0.11 & CL & 3 & 0.12 & 8 & 0.26 & 0.04 & 0.10 & 0.16 \\
\hline Licania kunthiana Hook.f. & 2 & & & 0.54 & 0.06 & $\mathrm{CL}$ & 2 & 0.08 & 8 & 0.26 & 0.01 & 0.02 & 0.12 \\
\hline Chrysobalanaceae & 6 & 21 & 5 & 11.22 & 1.31 & & 32 & & & & & IVIF & 1.66 \\
\hline \multicolumn{14}{|l|}{ Kielmeyera coriacea Mart. \& } \\
\hline Zucc. & 1 & & & 7.05 & 0.82 & PI & 1 & 0.04 & 4 & 0.13 & 0.00 & 0.01 & 0.06 \\
\hline Clusiaceae & 1 & 0 & 0 & 7.05 & 0.82 & & 1 & & & & & IVIF & 0.06 \\
\hline \multicolumn{14}{|l|}{ Connarus perrottetii (DC.) } \\
\hline Planch. var. & & 1 & & 0.36 & 0.04 & CL & 1 & 0.04 & 4 & 0.13 & 0.00 & 0.01 & 0.06 \\
\hline Connarus suberosus Planch. & 3 & 7 & 2 & 4.10 & 0.48 & PI & 12 & 0.49 & 36 & 1.16 & 0.24 & 0.67 & 0.77 \\
\hline Rourea induta Planch. & 1 & & & 0.27 & 0.03 & PI & 1 & 0.04 & 4 & 0.13 & 0.00 & 0.01 & 0.06 \\
\hline Connaraceae & 4 & 8 & 2 & 4.73 & 0.55 & & 14 & & & & & IVIF & 0.89 \\
\hline Davilla elliptica A.St.-Hil. & 6 & & & 1.63 & 0.19 & $\mathrm{CL}$ & 6 & 0.24 & 16 & 0.52 & 0.03 & 0.09 & 0.28 \\
\hline Dilleniaceae & 6 & 0 & 0 & 1.63 & 0.19 & & 6 & & & & & IVIF & 0.28 \\
\hline Diospyros hispida A.DC. & 2 & & & 0.54 & 0.06 & $\mathrm{CL}$ & 2 & 0.08 & 4 & 0.13 & 0.01 & 0.02 & 0.08 \\
\hline Dyospiros sericea A.DC. & & 3 & 3 & 2.14 & 0.25 & $\mathrm{CL}$ & 6 & 0.24 & 16 & 0.52 & 0.16 & 0.45 & 0.40 \\
\hline Ebenaceae & 2 & 3 & 3 & 2.68 & 0.31 & & 8 & & & & & IVIF & 0.48 \\
\hline Erythroxylum daphnites Mart. & 26 & 10 & & 10.78 & 1.26 & PI & 36 & 1.46 & 73 & 2.32 & 0.11 & 0.31 & 1.36 \\
\hline Erythroxylaceae & 26 & 10 & 0 & 10.78 & 1.26 & & 36 & & & & & IVIF & 1.36 \\
\hline Mabea fistulifera Mart. & 1 & 2 & & 1.00 & 0.12 & PI & 3 & 0.12 & 12 & 0.39 & 0.02 & 0.04 & 0.18 \\
\hline Maprounea guianensis Aubl. & 2 & 41 & 7 & 17.85 & 2.08 & CL & 50 & 2.03 & 101 & 3.22 & 0.44 & 1.25 & 2.17 \\
\hline Euphobiaceae & 3 & 43 & 7 & 18.85 & 2.20 & & 53 & & & & & IVIF & 2.35 \\
\hline Bowdichia virgilioides Kunth & & 6 & & 2.15 & 0.25 & $\mathrm{CL}$ & 6 & 0.24 & 16 & 0.52 & 0.11 & 0.31 & 0.36 \\
\hline Cenostigma macrophyllum Tul. & & 3 & 1 & 1.46 & 0.17 & $\mathrm{CL}$ & 4 & 0.16 & 16 & 0.52 & 0.05 & 0.15 & 0.28 \\
\hline Dalbergia densiflora Benth. & 1 & 2 & & 1.39 & 0.16 & $\mathrm{CL}$ & 3 & 0.12 & 12 & 0.39 & 0.02 & 0.04 & 0.18 \\
\hline Dalbergia miscolobium Benth. & 2 & 2 & & 1.27 & 0.15 & PI & 4 & 0.16 & 12 & 0.39 & 0.06 & 0.17 & 0.24 \\
\hline Dimorphandra gardineriana Tul. & 4 & & & 1.09 & 0.13 & CL & 4 & 0.16 & 16 & 0.52 & 0.02 & 0.04 & 0.24 \\
\hline Hymenaea martiana Hayne & 1 & & & 0.74 & 0.09 & $\mathrm{CL}$ & 1 & 0.04 & 4 & 0.13 & 0.01 & 0.03 & 0.07 \\
\hline \multicolumn{14}{|l|}{ Hymenaea stigonocarpa Mart. ex } \\
\hline Hayne & 1 & 2 & & 0.37 & 0.04 & $\mathrm{CL}$ & 3 & 0.12 & 12 & 0.39 & 0.06 & 0.18 & 0.23 \\
\hline Hymenolobium petraeum Ducke & 1 & & & 0.36 & 0.04 & PI & 1 & 0.04 & 4 & 0.13 & 0.00 & 0.01 & 0.06 \\
\hline Inga alba (Sw.) Willd. & 3 & 12 & 6 & 7.55 & 0.88 & CL & 21 & 0.85 & 32 & 1.03 & 0.27 & 0.76 & 0.87 \\
\hline Leptolobium dasycarpum Vogel & & 1 & 1 & 0.71 & 0.08 & $\mathrm{CL}$ & 2 & 0.08 & 8 & 0.26 & 0.08 & 0.23 & 0.18 \\
\hline $\begin{array}{l}\text { Parkia pendula (Willd.) Benth. } \\
\text { ex Walp. }\end{array}$ & & 1 & & 1.4 & 0.17 & $\mathrm{CL}$ & 1 & 0.04 & 4 & 0.13 & 0.2 & 0.59 & 0.25 \\
\hline Parkia platycephala Benth. & 5 & 29 & 15 & 25.26 & 2.95 & $\mathrm{CL}$ & 54 & 2.20 & 121 & 3.87 & 2.38 & 6.79 & 4.28 \\
\hline $\begin{array}{l}\text { Plathymenia reticulata Benth. } \\
\text { Tachigale vulgaris L.G.Silva \& }\end{array}$ & 4 & & & 1.27 & 0.15 & CL & 4 & 0.16 & 16 & 0.52 & 0.07 & 0.19 & 0.28 \\
\hline $\begin{array}{l}\text { H.C.Lima } \\
\text { Vatairea macrocarpa (Benth.) }\end{array}$ & 3 & 42 & 29 & 25.73 & 3.00 & PI & 73 & 2.93 & 121 & 3.87 & 1.53 & 4.36 & 3.72 \\
\hline Ducke & & 4 & & 1.47 & 0.17 & $\mathrm{CL}$ & 4 & 0.16 & 16 & 0.52 & 0.02 & 0.07 & 0.28 \\
\hline Faba & 25 & 104 & 52 & 72.25 & 8.43 & & 186 & & & & & IVIF & 11.52 \\
\hline Sacoglottis guianensis Benth. & 5 & 13 & 7 & 9.27 & 1.08 & CL & 25 & 1.02 & 52 & 1.68 & 0.24 & 0.68 & 1.12 \\
\hline Humiriaceae & 5 & 13 & 7 & 9.27 & 1.08 & & 25 & & & & & IVIF & 1.12 \\
\hline Emmotum nitens (Benth.) Miers & 20 & 204 & 54 & 98.03 & 11.44 & $\mathrm{CL}$ & 276 & 11.14 & 177 & 5.67 & 4.75 & 13.54 & 10.12 \\
\hline Icacinaceae & 20 & 204 & 54 & 98.03 & 11.44 & & 276 & & & & & IVIF & 10.12 \\
\hline Mezilaurus itauba (Meisn.) Taub. & & & & & & & & & & & & & \\
\hline $\begin{array}{l}\text { ex Mez } \\
\text { Ocotea pulchella (Nees \& Mart.) }\end{array}$ & 6 & 43 & 25 & 25.61 & 2.99 & $\mathrm{CL}$ & 74 & 2.97 & 73 & 2.32 & 1.43 & 4.08 & 3.12 \\
\hline Mez & 1 & & & 0.36 & 0.04 & CL & 1 & 0.04 & 4 & 0.13 & 0.04 & 0.11 & 0.09 \\
\hline Lauraceae & 7 & 43 & 25 & 25.97 & 3.03 & & 75 & & & & & IVIF & 3.21 \\
\hline $\begin{array}{l}\text { Lafoensia pacari A.St.-Hil. } \\
\text { Physocalymma scaberrimum }\end{array}$ & 1 & & & 4.99 & 0.58 & $\mathrm{CL}$ & 1 & 0.04 & 4 & 0.13 & 0.01 & 0.02 & 0.06 \\
\hline Pohl & 2 & 3 & 2 & 2.07 & 0.24 & CL & 8 & 0.24 & 12 & 0.39 & 0.16 & 0.45 & 0.36 \\
\hline
\end{tabular}


Table 1. Continuation.

\begin{tabular}{|c|c|c|c|c|c|c|c|c|c|c|c|c|c|}
\hline \multirow[b]{2}{*}{ Family/Species } & \multicolumn{5}{|c|}{ Vertical Structure } & \multirow[b]{2}{*}{ EG } & \multicolumn{7}{|c|}{ Horizontal Structure } \\
\hline & EI & EM & ES & PSA & PSR & & DA & DR & FA & FR & DoA & DoR & $\begin{array}{l}\text { IVI } \\
(\%)\end{array}$ \\
\hline Lythraceae & 3 & 3 & 2 & 7.06 & 0.82 & & 9 & & & & & IVIF & 0.42 \\
\hline Byrsonima coccolobifolia & & & & & & & & & & & & & \\
\hline Kunth & 5 & 8 & & 4.33 & 0.51 & $\mathrm{CL}$ & 13 & 0.53 & 44 & 1.42 & 0.12 & 0.33 & 0.76 \\
\hline $\begin{array}{l}\text { Byrsonima laxiflora Griseb. } \\
\text { Byrsonima pachyphylla }\end{array}$ & 3 & 26 & 1 & 10.75 & 1.25 & $\mathrm{CL}$ & 30 & 1.22 & 52 & 1.68 & 0.16 & 0.46 & 1.12 \\
\hline A.Juss. & 8 & 16 & & 8.08 & 0.94 & PI & 24 & 0.98 & 65 & 2.06 & 0.26 & 0.75 & 1.26 \\
\hline Byrsonima sericea DC. & $\begin{array}{c}3 \\
10\end{array}$ & 27 & 3 & 11.83 & 1.38 & $\mathrm{CL}$ & 33 & 1.34 & 81 & 2.58 & 0.52 & 1.48 & 1.80 \\
\hline $\begin{array}{l}\text { Malpignaceae } \\
\text { Eriotheca gracilipes }\end{array}$ & 19 & 77 & 4 & 35.00 & 4.08 & & 101 & & & & & & \\
\hline $\begin{array}{l}\text { A.Robyns } \\
\text { Eriotheca pubescens (Mart.) }\end{array}$ & 1 & 5 & & 1.81 & 0.21 & PI & 6 & 0.24 & 20 & 0.64 & 0.07 & 0.19 & 0.36 \\
\hline $\begin{array}{l}\text { Schott Endl. } \\
\text { Malvaceae }\end{array}$ & $\begin{array}{l}1 \\
2\end{array}$ & $\begin{array}{l}1 \\
6\end{array}$ & 0 & $\begin{array}{l}0.64 \\
2.46\end{array}$ & $\begin{array}{l}0.08 \\
0.29\end{array}$ & $\mathrm{CL}$ & $\begin{array}{l}2 \\
8\end{array}$ & 0.08 & 8 & 0.26 & 0.00 & $\begin{array}{c}0.02 \\
\text { IVIF }\end{array}$ & $\begin{array}{l}0.12 \\
0.48\end{array}$ \\
\hline Miconia albicans (Sw.) & & & & & & & & & & & & & \\
\hline Triana & 205 & 21 & & 64.62 & 7.54 & PI & 225 & 9.07 & 177 & 5.67 & 0.82 & 2.35 & 5.69 \\
\hline Miconia cuspidata Naudin & 1 & 30 & 11 & 15.01 & 1.75 & PI & 42 & 1.71 & 73 & 2.32 & 0.48 & 1.36 & 1.80 \\
\hline Miconia pepericarpa DC. & 4 & & & 1.09 & 0.13 & $\mathrm{CL}$ & 4 & 0.16 & 8 & 0.26 & 0.01 & 0.04 & 0.15 \\
\hline Mouriri glazioviana Cogn. & & 1 & & 0.36 & 0.04 & $\mathrm{CL}$ & 1 & 0.04 & 4 & 0.13 & 0.01 & 0.02 & 0.06 \\
\hline Mouriri pusa Gardner & & 2 & & 0.71 & 0.08 & $\mathrm{CL}$ & 2 & 0.08 & 8 & 0.26 & 0.23 & 0.66 & 0.33 \\
\hline Melastomataceae & 210 & 54 & 11 & 81.79 & 9.54 & & 274 & & & & & IVIF & 8.03 \\
\hline Virola sebifera Aubl. & 6 & 17 & 4 & 9.10 & 1.06 & PI & 27 & 1.10 & 61 & 1.93 & 0.24 & 0.70 & 1.24 \\
\hline Myristicaceae & 6 & 17 & 4 & 9.10 & 1.06 & & 27 & & & & & IVIF & 1.24 \\
\hline Myrcia multiflora (Lam.) DC. & & 3 & & 0.81 & 0.09 & CL & 3 & 0.12 & 8 & 0.26 & 0.01 & 0.03 & 0.14 \\
\hline Myrcia splendens (Sw.) DC. & 120 & 272 & 30 & 137.61 & 16.05 & PI & 419 & 16.91 & 141 & 4.51 & 5.57 & 15.86 & 12.43 \\
\hline Myrtaceae & 120 & 275 & 30 & 138.42 & 16.15 & & 422 & & & & & IVIF & 12.57 \\
\hline Ouratea ovalis (Pohl) Engl. & 8 & 16 & & 6.51 & 0.76 & $\mathrm{CL}$ & 24 & 0.98 & 61 & 1.93 & 0.13 & 0.37 & 1.09 \\
\hline Ochnaceae & 8 & 16 & 0 & 6.51 & 0.76 & & 24 & & & & & IVIF & 1.09 \\
\hline Agonandra brasiliensis & & & & & & & & & & & & & \\
\hline Hook.f. & 1 & & & 0.27 & 0.03 & $\mathrm{CL}$ & 1 & 0.04 & 4 & 0.13 & 0.00 & 0.01 & 0.06 \\
\hline Opiliaceae & 1 & 0 & 0 & 0.27 & 0.03 & & 1 & & & & & IVIF & 0.06 \\
\hline Roupala montana Aubl. & & 1 & & 0.37 & 0.04 & $\mathrm{CL}$ & 1 & 0.04 & 4 & 0.13 & 0.01 & 0.02 & 0.06 \\
\hline Proteaceae & 0 & 1 & 0 & 0.37 & 0.04 & & 1 & & & & & IVIF & 0.06 \\
\hline Alibertia edulis (Rich.) & & & & & & & & & & & & & \\
\hline $\begin{array}{l}\text { A.Rich. var. } \\
\text { Ferdinandusa elliptica (Pohl) }\end{array}$ & 3 & 1 & & 1.19 & 0.14 & $\mathrm{CL}$ & 4 & 0.16 & 16 & 0.52 & 0.01 & 0.03 & 0.24 \\
\hline Pohl & & 4 & 10 & 4.67 & 0.54 & $\mathrm{CL}$ & 14 & 0.57 & 28 & 0.90 & 0.83 & 2.35 & 1.27 \\
\hline Rubiaceae & 3 & 5 & 10 & 5.85 & 0.68 & & 18 & & & & & IVIF & 1.51 \\
\hline $\begin{array}{l}\text { Casearia arborea (Rich.) Urb. } \\
\text { Casearia grandiflora }\end{array}$ & & 5 & 1 & 2.22 & 0.26 & PI & 6 & 0.24 & 8 & 0.26 & 0.05 & 0.14 & 0.21 \\
\hline Cambess. & & 2 & & 0.74 & 0.09 & $\mathrm{CL}$ & 2 & 0.08 & 4 & 0.13 & 0.01 & 0.02 & 0.08 \\
\hline Salicaceae & 0 & 7 & 1 & 2.96 & 0.35 & & 8 & & & & & IVIF & 0.29 \\
\hline Matayba guianensis Aubl. & & 4 & 1 & 1.81 & 0.21 & $\mathrm{CL}$ & 5 & 0.20 & 16 & 0.52 & 0.04 & 0.12 & 0.28 \\
\hline Sapindaceae & 0 & 4 & 1 & 1.81 & 0.21 & & 5 & 0.20 & 16 & 0.52 & 0.04 & 0.12 & 0.28 \\
\hline Pouteria ramiflora (Mart.) & & & & & & & & & & & & & \\
\hline Radlk. & 12 & 12 & 5 & 10.27 & 1.20 & $\mathrm{CL}$ & 29 & 1.18 & 73 & 2.32 & 0.96 & 2.72 & 2.07 \\
\hline Sapotaceae & 12 & 12 & 5 & 10.27 & 1.20 & & 29 & & & & & IVIF & 2.07 \\
\hline Simarouba versicolor A.St.- & & & & & & & & & & & & & \\
\hline & 1 & 5 & 3 & 3.24 & 0.38 & $\mathrm{CL}$ & 9 & 0.37 & 24 & 0.77 & 0.11 & 0.32 & 0.49 \\
\hline Simaroubacea & 1 & 5 & 3 & 3.24 & 0.38 & & 9 & & & & & IVIF & 0.49 \\
\hline Siparuna guianensis Aubl. & 4 & 16 & 2 & 7.78 & 0.91 & $\mathrm{CL}$ & 22 & 0.89 & 40 & 1.29 & 0.15 & 0.43 & 0.87 \\
\hline Siparunaceae & 4 & 16 & 2 & 7.78 & 0.91 & & 22 & & & & & IVIF & 0.87 \\
\hline Qualea grandiflora Mart. & 25 & 2 & & 8.78 & 1.02 & $\mathrm{CL}$ & 27 & 1.10 & 81 & 2.58 & 0.27 & 0.75 & 1.48 \\
\hline Qualea multiflora Mart. & 2 & & & 0.74 & 0.09 & $\mathrm{CL}$ & 2 & 0.08 & 8 & 0.26 & 0.03 & 0.09 & 0.14 \\
\hline Qualea parviflora Mart. & 10 & 188 & 16 & 71.18 & 8.30 & $\mathrm{CL}$ & 213 & 8.58 & 173 & 5.54 & 2.85 & 8.13 & 7.42 \\
\hline Vochysia gardneri Warm. & 2 & 24 & & 9.61 & 1.12 & $\mathrm{CL}$ & 26 & 1.06 & 56 & 1.80 & 0.14 & 0.41 & 1.09 \\
\hline Vochysiaceae & 39 & 214 & 16 & 90.31 & 10.54 & & 268 & & & & & IVIF & 10.13 \\
\hline Total & 591 & 1565 & 325 & 857.2 & 100 & & 2482 & 100 & 3130 & 100 & 35.1 & 100 & 100 \\
\hline
\end{tabular}


Qualifying successional group of the sampled species resulted in find a higher density group composed by pioneer trees species (613 individuals $\mathrm{ha}^{-1}$ ) and climax species (530 individuals $\mathrm{ha}^{-1}$ ). Regarding the species richness, the climax group predominated (57 species) over the pioneer (25 species), although the number of trees in the pioneer group had been higher than in the climax group. The highest richness of climax species in the cerradão is represented by a mature vegetation. with good diversity of species (CONDÉ; TONINI, 2013).

The upper stratum of the cerradão showed $60 \%$ of climax group trees ( 25 species). especially for the species with timber potential Emmotum nitens (25 individuals $\left.\mathrm{ha}^{-1}\right)$. Mezilaurus itauba (12 individuals $\mathrm{ha}^{-1}$ ) and Parkia platycephala (7 individuals $\mathrm{ha}^{-1}$ ). The wood of these species is used in construction (lumber as rafters, timber and boards) and rural areas (beams, fences, boards for bridge construction). besides crates, liners, toys production. firewood and coal (CARVALHO, 2003; LORENZI, 2002).

The remaining trees in the upper stratum (40\%) are from pioneer groups (8 species). especially Tapirira guianensis (23 individuals $\mathrm{ha}^{-1}$ ). Myrcia splendens (14 individuals $\mathrm{ha}^{-1}$ ) and Tachigale vulgaris (13 individuals $\left.\mathrm{ha}^{-1}\right)$. Such species have large seed dispersal and rapid growth (CARVALHO; SILVA; DAVIDE, 2006). are generalists and grow in diverse phyto-physiognomies of the Cerrado and in other biomes (SOLÓRZANO et al., 2012). They are found in border and clearing areas and show good adaptability to poor and acids soils.

They are used in disturbed areas restoration projects and stand out for competition assays. due to the rapid growth of these species. being a promising forest species for energy production (CARVALHO, 2006; 2008). However, more studies are required to assess their commercial use potential. in order to develop management techniques for its sustainable use.

The sampled population was divided in 11 diameter classes. According to the Liocourt Quotient, the forest is balanced (Table 2). Before being a protected area, this area suffered with logging, as evidenced by the presence of extraction residues. The Liocourt Quotient (q) values of the first eight classes showed that the horizontal structure of the cerradão arboreal vegetation is balanced, since the "q" values was relatively constant (MEYER, 1951). This result shows that the vegetation is recovering its horizontal structure in a balanced manner, despite the disturbance in the cerradão before the park protection.

Table 2. Absolute and relative frequency distribution and Liocourt Quotient values. by diameter class of trees with $\mathrm{DBH} \geq$ $5 \mathrm{~cm}$ sampled in a cerradão fragment of Palmas, Tocantins, Brazil.

\begin{tabular}{cccccccc}
\hline \multicolumn{2}{c}{ Classes de DBH } & $\begin{array}{c}\text { FR } \\
\text { Pioneers }\end{array}$ & $\begin{array}{c}\text { FR } \\
\text { Climax }\end{array}$ & $\begin{array}{c}\text { FR Pioneer } \\
+ \text { Clímax }\end{array}$ & $\begin{array}{c}\text { FR } \\
\text { Relative }\end{array}$ & "q" \\
\hline 5 & - & 10 & 754 & 510 & 1,264 & 50.95 & 2.03 \\
10 & - & 15 & 345 & 277 & 622 & 25.07 & 2.05 \\
15 & - & 20 & 164 & 140 & 304 & 12.25 & 2.04 \\
20 & - & 25 & 46 & 103 & 149 & 6.01 & 2.04 \\
25 & - & 30 & 15 & 58 & 73 & 2.94 & 2.15 \\
30 & - & 35 & 7 & 27 & 34 & 1.37 & 2.00 \\
35 & - & 40 & 3 & 6 & 14 & 0.69 & 2.13 \\
40 & - & 45 & 2 & 4 & 4 & 0.32 & 2.00 \\
45 & - & 50 & - & 2 & 2 & 0.16 & 1.33 \\
50 & - & 55 & - & 1 & 1 & 0.12 & 1.50 \\
55 & - & 60 & - & 1,145 & 2,481 & 0.08 & 2.00 \\
60 & - & 65 & - & & & 0.04 & - \\
\hline
\end{tabular}

$\mathrm{FR}=$ frequency; "q" = Liocourt Quotient.

The diameter distribution curve showed a negative exponential pattern resembling a reversed $\mathrm{J}$, which describes a typical pattern of diameter distribution in native forests (CONDÉ; TONINI, 2013; GONÇALVES; SANTOS, 2008).

Regarding the diametric distribution of the successional groups, the pioneer group predominated in the first three diametric classes, with the climax group predominating from the fourth diametric class (Figure 2). The sampled trees were distributed in height classes (EI, EM and ES) and subdivided into pioneer and climax (Figure 2). The highest density of trees $(87 \%)$ was part of the mid and lower stratum of the forest, and only $14 \%$ had heights higher than $11.54 \mathrm{~m}$. 


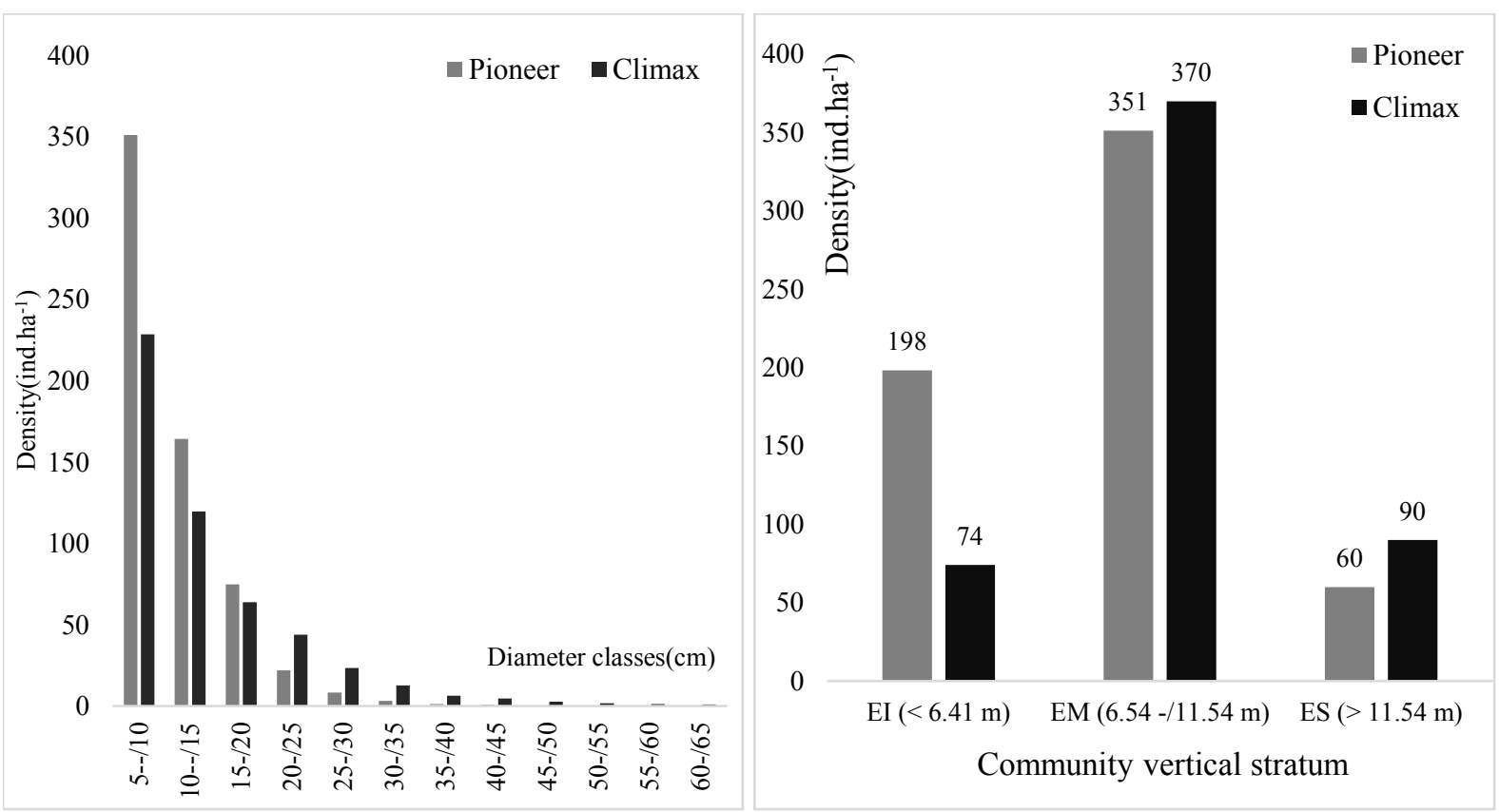

Figure 2. Individual frequency per hectare by diametric class per successional group (A); individual frequency per hectare by strata class in height; (B) Height classes (EI = lower stratum; EM = mid stratum; ES = upper stratum) per successional group in a cerradão of Palmas, Tocantins, Brazil.

The first diameter class was responsible for more than $50 \%$ of all sampled trees and only $3.15 \%$ of them showed diameter higher than $30 \mathrm{~cm}$. The large tree density in the smaller diameter classes was able to provide part of their representatives to the upper diameter classes. during future periods, assisting in the dynamic and enabling the vegetation continuity. However, exceptions are considered if there is some kind of disturbance, natural or anthropic. The species with higher diameters were Parkia platycephala $(65 \mathrm{~cm})$, Caryocar coriaceum $(54.6 \mathrm{~cm})$, Emmotum nitens $(52.3 \mathrm{~cm})$ and Mezilaurus itauba $(50.2 \mathrm{~cm})$.

Ferdinandusa elliptica (21 m), Emmotum nitens $(19 \mathrm{~m})$, Tachigale vulgaris $(19 \mathrm{~m})$, Tapirira guianensis $(18.5 \mathrm{~m})$ and Mezilaurus itauba $(18 \mathrm{~m})$ stood out as the highest species. According to Souza et al. (2008), the Cerrado and other biomes may change its horizontal and vertical structure along the flora adaptation process, depending on which factors its vegetation is exposed to, regardless its floristic origin.

This process is more evident in areas where transitions or contacts between different kinds of vegetation are possible. In Tocantins State, the confluence of Amazon Forest and Cerrado areas are characterized by wide climatic and physical environment variations, and this diversity enables changes in the species floristic, structure and growth (HAIDAR et al., 2013; SILVA et al., 2006). Therefore, the studied cerradão showed a typical species of the Amazon biome (Mezilaurus itauba) and higher values of height $(21 \mathrm{~m})$ and diameter $(65$ $\mathrm{cm}$ ) compared to other studied areas of cerradão
(SILVA, 2009; GUILHERME; NAKAJIMA, 2007; SALIS et al., 2006).

\section{CONCLUSIONS}

Based on this research results we concluded that: a) The floristic composition was dominated by the Fabaceae and Chrysobalanaceae families and by the Myrcia splendens, Emmotum nitens, Qualea parviflora, Xylopia aromatica and Tapirira guianensis tree species; (b) The dominant tree species characterized the study area as dystrophic with high species richness; (c) The floristic and phytosociological compositions found in the studied site showed that the cerradão can be considered a well-structured and diverse vegetation type, which showed good conservation condition, considering that the tree species diversity were mainly composed by climax species; (d) The cerradão showed a balanced diametric distribution that indicates its resilience to small disturbances.

\section{REFERENCES}

ABREU, T. A. L; PINTO, J. R. R; MEWS, H. A. Variações na riqueza e na diversidade de espécies arbustivas e arbóreas no período de 14 anos em uma Floresta de Vale, Mato Grosso, Brasil. Rodriguésia, Rio de Janeiro, v. 65, n. 1, p. 13-88, 2014.

ARAÚJO, R. A. et al. Florística e estrutura de 
fragmento florestal em área de transição na Amazônia Matogrossense no município de Sinop. Acta Amazônica, Manaus, v. 39, n. 4, p. 865-877, 2009.

ANGIOSPERM PHYLOGENY GROUP III (APG III). An update of the Angiosperm Phylogeny Group classification for the orders and families of flowering plants: APG III. Botanical Journal of the Linnaean Society, London, v. 161, n. 4, p. 105-121, 2009.

CAMILOTTI, D. C; PAGOTTO, T. C. S; ARAUJO, A. C. Análise da vegetação arbórea de um remanescente de Cerradão em Bandeirantes, Mato Grosso do Sul, Brasil. Iheringia, Série Botânica, Porto Alegre, v. 66, n. 1, p. 31-46, 2011.

CARVALHO, P. E. R. Espécies arbóreas brasileiras. v. 3. Colombo, PR: Embrapa Florestas, 2008. 593 p.

CARVALHO, P. E. R. Espécies arbóreas brasileiras. v. 2. Colombo, PR: Embrapa Florestas, 2006. $627 \mathrm{p}$.

CARVALHO, P. E. R. Espécies arbóreas brasileiras. v. 1. Colombo, PR: Embrapa Florestas, 2003. 1039 p.

CARVALHO, L. R; SILVA, E. A. A; DAVIDE, A. C. Classificação de sementes florestais quanto ao comportamento no armazenamento. Revista Brasileira de Sementes, Pelotas, v. 28, n. 2, p. 1525, 2006.

CONDÉ, T. M; TONINI, H. Fitossociologia de uma Floresta Ombrófila Densa na Amazônia Setentrional, Roraima, Brasil. Acta Amazonica, Manaus, v. 43, n. 3, p. 247-260, 2013.

CIENTEC. Software Mata Nativa: manual do usuário. Viçosa: CIENTEC, 2001. 131 p.

COSTA, A. A.; ARAÚJO, G. M. Comparação da vegetação arbórea de cerradão e cerrado na Reserva do Panga, Uberlândia, Minas Gerais. Acta Botânica Brasílica, São Paulo, v. 15, n. 1, p. 63-72, 2001.

EMBRAPA. O Novo mapa de solos do Brasil. 3. ed. Rio de Janeiro, RJ: EMBRAPA-CNPS, 2011. 67 p.

FELFILI, J. M.; CARVALHO, F. A.; HAIDAR, R. F. Manual para o monitoramento de parcelas permanentes nos biomas Cerrado e Pantanal. v. 1. Brasília, DF: UnB, 2005. 51 p.

FELFILI, J. M. et al. Diversity, floristic and structural patterns of cerrado vegetation in Central Brasil. Plant Ecology, Dordrecht, v. 175, n. 1, p. 37 -
$46,2004$.

FINOL, U. H. Nuevos parametros a considerarse en el análisis estrutural de las selvas vírgenes tropicales. Revista Forestal Venezolana, Mérida, v. 18, n. 12, p. 29-42, 1971

FRANCEZ, L. M. B; CARVALHO, J. O. P; JARDIM, F. C. S. Mudanças ocorridas na composição florística em decorrência da exploração florestal em uma área de floresta de Terra Firme na região de Paragominas, PA. Acta Amazonica, Manaus, v. 37, n. 2, p. 219-228, 2007.

GONÇALVES, F. G.; SANTOS, J. R. Composição florística e estrutura de uma unidade de manejo florestal sustentável na Floresta Nacional do Tapajós, Pará. Acta Amazonica, Manaus, v. 38, n. 2, p. 229 $244,2008$.

GUILHERME， F. A. G.; NAKAJIMA， J. N. Estrutura da vegetação arbórea de um remanescente ecotonal urbano floresta-savana no Parque do Sabiá, em Uberlândia, MG. Revista Árvore, Viçosa, v. 31, n. 2, p. 329-338, 2007.

HAIDAR, R, F. et al. Florestas estacionais e áreas de ecótono no estado do Tocantins, Brasil: parâmetros estruturais, classificação das fitofisionomias florestais e subsídios para conservação. Acta Amazonica, Manaus, v. 43, n. 3, p. 261-290, 2013.

HARIDASAN, M.; ARAÚJO, G. M. Perfil nutricional de espécies lenhosa de uma floresta semidecíduas em Ubrlândia, MG. Revista Brasileira de Botânica, São Paulo, v. 28, n. 2, p. 295-303, 2005 .

KENT, M.; COKER, P. Vegetation Description and Analysis - A Pratical Approach. 2. ed. Chichester: John Wiley and Sons, 1999. 363 p.

KOPPEN. W. Das geographische System der Klimate. In: W. KÖPPEN; R. GEIGER (Eds.). Handbuch der Klimatologie. Berlin: Gebrüder Bornträger, 1936. v. 1, part C. p. 1-44.

LORENZI, H. Árvores Brasileiras - Manual de Identificação e Cultivo de Plantas Árboreas Nativas do Brasil. v. 2. Nova Odessa, SP: Instituto Plantarum, 2002. 384 p.

MAGURRAN, A. E. Measuring biological diversity. 2. ed. Oxford: Blackwell Publishing 2004, $215 \mathrm{p}$.

MARIMON-JUNIOR, B. H.; HARIDASAN, M. Comparação da vegetação arbórea e características edáficas de um cerradão e um cerrado sensu stricto 
em áreas adjacentes sobre solo distrófico no leste de Mato Grosso, Brasil. Acta Botanica Brasilica, São Paulo v. 19, n. 4, p. 913-926, 2005.

MENDONÇA, R. C et al. Flora vascular do cerrado: Checklist com 12.356 espécies. In SANO, S. M.; ALMEIDA, S. P.; RIBEIRO, J. F. (Eds.). Cerrado: Ecologia e Flora. Brasília: Embrapa Cerrados, 2008. v. 2, cap. 15 , p. $417-1279$.

MEYER, A. H. et al. Forest management. 1. ed. New York, NY: The Ronald Press Company, 1961. $82 \mathrm{p}$.

MEYER, A. H. Structure, Growth, and Drain in Balanced Uneven-Aged Forests. Journal of Forestry, Washington, v. 50, n. 2, p. 85-92, 1951.

MORI, S. A. et al. Manual de manejo do herbário fanerogâmico. 24 ed. Salvador, BA: CEPLAC, 1989. $104 \mathrm{p}$.

MORI, A. S.; BOOM, B. Ecological importance of myrtaceae in an eastern brazilian wet forest. Biotropica, Malden, v. 15, n. 1, p. 68-70, 1983.

MÜELlER-DOMBOIS, D.; ELLENBERG, H. Aims and methods of vegetation ecology. 2nd ed. New Jersey: The Blackburn Press, 2002. 547 p.

MYERS, N. et al. Biodiversity hotspots for conservation priorities. Nature, London, v. 403, n. 8, p. $853-858,2000$.

OLIVEIRA, L. C. et al. Composição e diversidade florístico-estrutural de um hectare de floresta densa de terra firme na Amazônia Central, Amazonas, Brasil. Acta Amazonica, Manaus, v. 38, n. 4, p. $627-$ 642, 2008.

PÉLICO NETTO, S.; BRENA, D. A. Inventário Florestal. v. 1. Curitiba, PR: UFPR, 1997. 316 p.

PIRES - O'BRIEN, M. J.; O'BRIEN, C. M. Ecologia e modelamento de florestas tropicais. v. 1. Belém, PA: FCAP, 1995. 400p.

PROENÇA, C. E. B et al. Listagem e nível de proteção das espécies de fanerógamas do Distrito Federal, Brasil. In: CAVALCANTI, T. B.; RAMOS, A. E. (Eds.). Flora do Distrito Federal I. Brasília: Embrapa cenargen, 2001. v. 1, cap. 2, p. 89-359.

RATTER, J. A.; RIBEIRO, J. F.; BRIDGEWATER, S. The Brazilian Cerrado Vegetation and Threats to its Biodiversity. Botanical Briefing, Oxford, v. 80, n. 3, p. 223-230, 1997.

RATTER, J. A. Notes on the vegetation of the Parque Nacional do Araguaia (Brazil). Notes Royal
Botanic Garden, Edimburgh, v. 44, n. 2, p. 311-342, 1987.

RATTER, J. A. et al. Observations on the vegetation of north eastern Mato Grosso I: The woody vegetation types of the Xavantina-Cachimbo Expedition Area. Philosophical Transactions of the Royal Society of London B, London, v. 226, n. 880, p. 449-492. 1973.

RATTER, J. A. Some notes on two types of cerradão occurring in northeastern Mato Grosso. In: FERRI, M. G. (eds.). III Simpósio Sobre o Cerrado. São Paulo: Edgard Blucher, 1971.p, 100-102.

RESSEL, K. et al. Ecologia morfofuncional de plântulas de espécies arbóreas da Estação Ecológica do Panga, Uberlândia, Minas Gerais. Brazilian Journal of Botany, São Paulo, v. 27, n. 2, p. 311 323, 2004.

RIBEIRO, J. F.; WALTER, B. M. T. As principais fitofisionomias do Bioma Cerrado. In: SANO, S. M.; ALMEIDA, S. P.; RIBEIRO, J. F. (eds.). Cerrado: Ecologia e Flora. Brasília: Embrapa Cerrados, 2008. v. 1 , cap. 6 , p. 151-212.

RODRIGUES, R. R. et al. Tree species sprouting from root buds in a semideciduous forest affected by fi res. Brazilian Archives of Biology and Technology, Curitiba, v. 47, n. 1, p. 127-133, 2004.

SALIS, S. M. et al. Distribuição e abundância de espécies arbóreas em cerradões no Pantanal,

Estado do Mato Grosso do Sul, Brasil. Brazilian Journal of Botany, São Paulo, v. 29, n. 3, p. 339$352,2006$.

SANTOS, J. H. S. et al. Distinção de grupos ecológicos de espécies florestais por meio de técnicas multivariadas. Revista Árvore, Viçosa, v. 28, n. 3, p. 387-396, 2004.

SCHILlinG, A. C.; BATISTA, J. L. F. Curva de acumulação de espécies e suficiência amostral em florestas tropicais. Revista Brasileira de Botânica, São Paulo, v. 31, n. 1, p. 179-187, 2008.

SILVA, H. G.; FIGUEIREDO, N.; ANDRADE, G. V. Estutura da vegetação de um cerradão e a heterogeneidade regional do Cerrado no Maranhão, Brasil. Revista Árvore, Viçosa, v. 32, n. 5, p. 921930, 2008 .

SILVA, J. F. et al. Spatial heterogeneity, land use and conservation in the cerradão region o Brazil. Journal of Biogeography, Oxford, v. 33, n. 3, p. 536-548, 2006.

SOLÓRZANO, A. et al. Perfil florístico e estrutural 
do componente lenhoso em seis áreas de cerradão ao longo do bioma Cerrado. Acta Botanica Brasilica, Feira de Santana, v. 26 n. 2. p. 328-341, 2012.

SOUZA et al. Emprego de análise multivariada para estratificação vertical de florestas ineqüiâneas. Revista Árvore, Viçosa, v. 27, n. 1, p. 59-63, 2003.

SOUZA, P. B. et al. Composição florística da vegetação arbórea de um remanescente de cerradão, Paraopeba, MG. Revista Árvore, Viçosa, v. 32, n. 4, p. 771-780, 2008.

SOUZA, P. B. et al. Florística de uma área de cerradão na floresta nacional de Paraopeba - Minas Gerais. Revista Cerne, Lavras, v. 16, n. 1, p. 86-93, 2010.

SWAINE, M. D.; WHITMORE, T. C. On the definition of ecological species groups in tropical rain forests. Vegetatio, Dordrecht, v. 75, n. 1-2, p. 81 $-86,1988$.

TOPPA, R. H.; PIRES, J. S. R.; DURIGAN, G. Flora lenhosa e síndromes de dispersão nas diferentes fisionomias da vegetação da Estação Ecológica de Jataí, Luiz Antônio, Hoehnea, São Paulo, v. 32, n.1, p. 67-76, 2004. 